\title{
Immediate reactions after mRNA SARS-CoV-2 vaccination
}

\author{
Samira Jeimy MD PhD, Tiffany Wong MD, Christine Song MD
}

Cite as: CMAJ 2021 December 6;193:E1842. doi: 10.1503/cmaj.211581; early-released November 12, 2021

\section{1} Anaphylaxis after mRNA vaccination for SARS-CoV-2 is rare

Reported rates of anaphylaxis are 4.7 per million for the Pfizer-BioNTech vaccine and 2.5 per million for Moderna. ${ }^{1}$ No fatal allergic reactions have been reported, possibly because of rapid identification and treatment.

2

An immediate reaction to the first dose of the mRNA vaccines should not preclude administration of the second dose

In a retrospective case series of 189 people who reported immediate reactions to the first vaccine dose, a second dose was successfully administered to $159 .{ }^{2}$ Nonspecific and single-system reactions (e.g., flushing, hives, lightheadedness) to the first dose were more common than anaphylaxis, ${ }^{2}$ and these can be mitigated by counselling and conservative treatment, including second-generation antihistamines.

\section{Excipient skin testing is not useful ${ }^{3,4}$}

In a case series of 80 people, $81 \%$ of whom had immediate-onset reactions to mRNA vaccines, $18 \%$ had positive skin tests to polyethylene glycol (PEG) or to polysorbate-80, which is structurally similar. However, $89 \%$ tolerated the second dose, including those with positive skin tests. ${ }^{4}$ This argues against the presence of anti-PEG immunoglobulin (Ig) E antibodies.

Reactions to mRNA SARS-CoV-2 vaccines may not be mediated by IgE antibodies

The mechanism of mRNA vaccine reactions is unknown. Liposomes, like those in the mRNA vaccines, can trigger complement activation-related pseudoallergy, leading to mast cell degranulation. The same mechanism mediates reactions to other liposomal medications, such as liposomal doxorubicin. Pseudoallergy may explain why people with immediate reactions to their first dose are able to tolerate subsequent doses. ${ }^{5}$

\section{Rapid allergist assessment for mRNA vaccine administration is now accessible across Canada}

The National Advisory Committee on Immunizations recommends that people with suspected allergic reactions after a first dose of an mRNA vaccine can receive additional doses of any mRNA vaccine, in consultation with an allergist. Expedited allergist assessments can be conducted in person (https://cirnetwork.ca/sic-network-patient-referrals/) or via an electronic platform (https://otnhub.ca).

\section{References}

1. Shimabukuro TT, Cole M, Su JR. Reports of anaphylaxis after receipt of mRNA COVID-19 vaccines in the US: December 14 2020-January 18, 2021. JAMA 2021;325:1101-2.

2. Krantz MS, Kwah JH, Stone CA Jr, et al. Safety evaluation of the second dose of messenger RNA COVID-19 vaccines in patients with immediate reactions to the first dose. JAMA Intern Med 2021;181:1530-3.

3. Mark C, Gupta S, Punnett A, et al. Safety of administration of BNT162b2 mRNA (Pfizer-BioNTech) COVID-19 Vaccine in youths and young adults with a history of acute lymphoblastic leukemia and allergy to PEG-asparaginase. Pediatr Blood Cancer 2021;68:e29295.

4. Wolfson AR, Robinson LB, Li L, et al. First dose mRNA COVID19 vaccine allergic reactions: limited role for excipient skin testing. J Allergy Clin Immunol Pract 2021;9:3308-20.e3.

5. Warren CM, Snow TT, Lee AS, et al. Assessment of allergic and anaphylactic reactions to mRNA COVID-19 vaccines with confirmatory testing in a US regional health system. JAMA Netw Open 2021;4:e2125524.

\section{Competing interests: None declared.}

This article has been peer reviewed.

Affiliations: Division of Clinical Immunology and Allergy (Jeimy), Department of Medicine, Western University, London, Ont.; Division of Allergy and Immunology (Wong), Department of Pediatrics, The University of British Columbia, Vancouver, BC; Division of Clinical Immunology and Allergy (Song), Department of Medicine, University of Toronto, Toronto, Ont.

Content licence: This is an Open Access article distributed in accordance with the terms of the Creative Commons Attribution (CC BY-NC-ND 4.0) licence, which permits use, distribution and reproduction in any medium, provided that the original publication is properly cited, the use is noncommercial (i.e., research or educational use), and no modifications or adaptations are made. See: https://creativecommons. org/licenses/by-nc-nd/4.0/

Correspondence to: Samira Jeimy, samira.jeimy@lhsc.on.ca 